\title{
Responding to the Post 9/11 Structural and Operational Challenges of Global Jihad
}

\section{Rohan Gunaratna*}

\section{Introduction}

The efficiency and effectiveness of state, societal, and international responses against Islamic radicalism and its by-product, terrorism, are grossly insufficient. The post-9/11 environment has witnessed an escalation rather than a diminution in threat. While the pre-9/11 environment witnessed an average of one attack every year by Al Qaeda, the post-9/11 era has brought an attack by Al Qaeda or its associated groups once every three months. In some theatres, such as Iraq, Afghanistan, Chechnya, and Saudi Arabia, the attacks are more frequent.

Our knowledge and understanding of Islamist groups have grown several-fold in the wake of the September 11 attacks. As a result of several hundred debriefings of $\mathrm{Al}$ Qaeda detainees, communication intercepts, and recoveries from Afghanistan and other safe havens, we now know many of its structural and operational details. Nonetheless, the traditional concepts and tools we are using to fight terrorism have proved inefficient and ineffective against the new wave of terrorism. After a reappraisal of the threat, this article will discuss the strengths and weaknesses of the various approaches and strategies for combating terrorism.

\section{The Context}

As opposed to clearly-defined terrorist groups and their support bases, most twentyfirst-century governments are confronted with amorphous terrorist networks. The formation of partnerships - loose cooperative networks and alliances between terrorist groups - has increased the staying power of terrorist organizations and their ideologies. Over three years before George W. Bush formed a global coalition to combat $\mathrm{Al}$ Qaeda and its associates in October 2001, Osama bin Laden formed the World Islamic Front for Jihad Against the Jews and the Crusaders in February 1998. ${ }^{1}$ The World Islamic Front for Jihad against the Jews and the Crusaders, known as Al-Jabha al-Islaamiyya lil-Jihad Dudda al-Yahood wal-Saliibiyeen, is the largest alliance of Islamist groups ever assembled.

The expanding ideological and operational linkages between local, regional, and global terror networks are forcing governments to belatedly develop a better understanding of who is talking to whom and who is working with whom. Instead of only

* Rohan Gunaratna is the author of Inside Al Qaeda: Global Network of Terror (New York: Columbia University Press, 2002), and is currently an associate professor at the Institute of Defense and Strategic Studies in Singapore.

1 "World Islamic Front for Jihad Against Jews and Crusaders," released by Al Qaeda, February 1998. 
monitoring and reporting, even the security services - the guardians of nations - are moving towards a truly operational agenda. Due to the growing linkages between domestic and foreign terrorist groups, governments have no option but to aggressively target and erode the ideological, personnel, and physical infrastructures of threat groups and their resilient networks. To be successful, governments should move from traditional cooperation to collaboration. A network of terrorist networks can be effectively targeted only by a network of government networks.

Unless governments realize that terrorism is a common threat that requires an international as well as a comprehensive response, they will fail to stem the global rise in terrorism. To reduce the threat of political violence, governments should closely monitor and counter both the rapid development and transfer of terrorist capabilities across regions, conflicts, and groups.

\section{Background}

Two landmark events, both of which took place in 1979, precipitated the global rise of Islamist extremism and terrorism. ${ }^{2}$ After the successful defiance of one superpower and the defeat of another, the successes of the Iranian revolution (1979) and the anti-Soviet multinational Afghan campaign (1979-89) instilled the belief among a segment of Muslim youth that they could take on the United States. A year before the Soviet military-the world's largest-withdrew in humiliation from Afghanistan, Dr. Abdullah Azzam, a Palestinian-Jordanian cleric who was the principal ideologue of the Afghan anti-Soviet campaign, conceptualized Al Qaeda Al Sulbah (The Solid Base) as the vanguard of the Islamist movement. When Al Qaeda was founded by Azzam and his deputy and protégé Osama bin Laden in March of 1988, the Palestinian-Jordanian scholar wanted the group to play a leadership role in conflict zones where Muslims were suffering. ${ }^{3}$ Al Qaeda evolved from the Afghan Service Bureau (Maktab-ilKhidamat), an organization established by Azzam and bin Laden at the height of the anti-Soviet campaign in 1984. Therefore, Al Qaeda rank-and-file members directly benefited and drew from an earlier generation of organizational and operational expertise and experience. However, the true strength of Al Qaeda is in its appealing ideology of global jihad both for Al Qaeda and other Islamist parties and groups.

Today this ideology - drawn from historical events, and tested by fire in Afghanistan, Chechnya, and Iraq - continues to resonate in the Muslim world. These events remain the principal sources of inspiration for the Islamist rank-and-file directly engaged in the fight, as well as for the wider support base sustaining the struggle. In addition, the Iranian revolution, the anti-Soviet campaign, and now the resistance in Iraq have politicized several hundred thousand Muslims worldwide. Their aftereffects con-

2 For a survey of Islamist fundamentalism, see Lawrence Davidson, Islamic Fundamentalism (Westport, CT: Greenwood Press, 1998).

3 Reuven Paz, Tangled Web: International Networking of the Islamist Struggle (Washington, D.C.: Washington Institute for Near East Policy, 2002), Appendix 1. "Al-Qa'idah al-Sulbah." 
tinue to radicalize and mobilize Muslim territorial and migrant communities worldwide. Even today, after the total destruction of the Al Qaeda training and operational infrastructure in Afghanistan, neither Al Qaeda nor other Islamists have had difficulty recruiting members or replenishing its losses, either in material (firearms or finances) or personnel (dead and injured). Al Qaeda and other groups have managed to build in the strictest secrecy a robust and resilient organizational structure.

The global fight against Islamist extremism and terrorism will be the defining conflict of the early twenty-first century. Osama Bin Laden has built an organization that functions both operationally and ideologically at the local, national, regional, and global levels. Defeating Al Qaeda and its associated groups will be a key challenge that will dominate not only the agendas of the international security and intelligence community, law enforcement authorities, and national military forces, but a range of other actors in the foreseeable future. To terrorize Western governments, their societies, and their friends in the Muslim world, violent Islamist ideologues such as Abu Qatada, Abu Hamza Al Masri, Abu Muhammad Al Masri, Safar Al Hawali, and Salman Al Ouda have recruited and generated support from territorial and emigrant Muslim communities around the world. Even after allied and coalition troops, led by the U.S., have destroyed its training and operational infrastructure in Afghanistan, Al Qaeda, which has now transformed from a group to a movement, poses an unprecedented terrorist threat to international peace and security. Although Bin Laden is likely to be killed or die of illness, he has crafted and popularized an ideology that continues to inspire and instigate his Muslim followers to oppose the "enemies of Islam." The largely military response of the international community during the first two and half years after 9/11 has failed to reduce the threat. In fact, the terrorist threat has escalated substantially since September of 2001.

The governmental and societal response against the background of the evolving terrorist threat after $9 / 11$ demonstrates that the contemporary wave of terrorism will gather momentum. Despite billions of dollars having been devoted to fighting terrorism, the threat persists, and is more severe than before. Combating terrorism has become a top national security priority. Nonetheless, terrorist campaigns are intractable. They require a comprehensive approach versus a single-pronged attack, and a shared versus a unilateral response.

\section{Post-Al Qaeda Threat}

Three years after the attacks of 9/11, Al Qaeda per se-a group that in October of 2001 had an estimated membership of only 4000 members - is operationally weak, and is no longer able to mount 9/11-style attacks on Western soil. Nonetheless, several Middle Eastern, South Asian, Southeast Asian, Central Asian, and African groups have adopted Al Qaeda's technologies, tactics, and techniques. Although Al Qaeda's strength is limited to a few hundred members today, its ideology of a global jihad is inspiring and instigating at least three-dozen Islamist groups worldwide. Al Qaeda's single biggest contribution has been its ability to spur Islamist groups worldwide to fight at two levels: against the near or domestic enemy - their own governments - as well as against the distant or the far enemy - the U.S. and its allies. While refusing to die, Al 
Qaeda - the most hunted terrorist group in history - is contributing to the sustenance of a global Islamist insurgency.

In the post-9/11 strategic environment, multiple new groups have emerged. In power vacuum left in Iraq in the wake of the fall of the Hussein regime, the space available for the Islamist groups to grow has further expanded. With increasing space and resources, the Islamist threat is growing exponentially. With the intention of reducing the terrorist threat, the international community continues to forge and implement a wide range of security and counter-security measures. The military action in Afghanistan has dismantled the Islamist training infrastructure, and intensified intelligence and law enforcement measures in target countries have reduced the immediate threat for the next one to two years. Nonetheless, the anti- and counter-terrorist measures offer no permanent solution. While terrorist capabilities have suffered, their intentions remain the same. As the events of 3/11 in Madrid demonstrated, after painstakingly analyzing the post-9/11 security architecture, the terrorists identified its loopholes and gaps, and attacked Europe.

As a result of the U.S.-led coalition intervention in Afghanistan, both Al Qaeda and its associated members have dispersed from the core of Afghanistan and Pakistan into lawless zones around the world. These regions include Iraq, especially its border with Iran; Somalia, a conflict of international neglect; Yemen, where only 35 percent of the nation's territory is under government control; Kashmir, a conflict zone bordering Afghanistan; the Myanmar-Bangladesh border; the southern Philippines; and other conflict zones. Both Al Qaeda and its associate members are using these bases to launch attacks against the U.S. and its allies.

\section{Post-Afghanistan Terrorist Architecture}

In place of Khalid Sheikh Muhammad, the former head of the Al Qaeda military committee, several commanders have emerged in Southeast Asia, South Asia, the Persian Gulf, North Africa, Horn of Africa, the Levant, and the Caucasus. While some of them have been killed or captured, others still operate. For instance, Isamuddin Riduan (alias Hambali) was captured by the Thai Special Branch II in Central Thailand on 11 August 2003, and Khalid Ali Al Haji (alias Hazim Al Sh'ir) - Al Qaeda's chief of Gulf operations-was killed by the Saudi security forces in Saudi Arabia on 15 March 2004. Fazul Abdullah Muhammad (alias Haroon) - the chief of East Africa operations, however, is still alive and at large. After Khalid Sheikh Muhammad was captured in Pakistan by its Inter-Services-Intelligence and the CIA on 2 March 2003, a de facto operational commander of the Al Qaeda network has emerged.

After the U.S. invasion of Iraq, and especially after the gruesome beheading of Nick Berg, Ahmad Fadil Nazal Al-Khalayleh (alias Abu Musab Al Zarqawi), a Jordanian from Zarka, set himself up as a rising figure in the Al Qaeda network. Although his main base of operations is in Iraq, he has built a network that extends into Europe and North America. Given the extent of the networks he has been able to assemble since 9/11, he may today be considered the de facto operational chief of the Al Qaeda movement. Despite his differences with Osama bin Laden over the targeting of Shia 
Muslims, Al Zarqawi has managed to absorb multiple Islamist support networks or transform them into operational networks.

\section{Al Zarqawi: The Next Generation?}

Al Zarqawi, a veteran of the anti-Soviet multinational Afghan jihad, was not known to the outside world in the $1980 \mathrm{~s}$. He came to the attention of international security services in the late 1990s, after he started to work with Al Qaeda in 1999. While jailed in Jordan from 1992-97, Al Zarqawi came under the ideological sway of the Jordanian cleric Abu Muhammad Maqdisi, and thereafter of Abu Qatada, who is based London. ${ }^{4}$ From 1997 to 1999, Al Zarqawi plotted to overthrow the Jordanian government and attempted to conduct operations against Israel. Like the three-dozen Islamist groups that have received support from Al Qaeda, Al Zarqawi also received facilities and funds from Al Qaeda to train Jordanians and Palestinians, nationalities that had not previously figured prominently in Al Qaeda's membership. He established Al Tawhid in Europe, primarily in Germany, and joined forces with Ansar Al Islam in northern Iraq.

After September 2001, Al Zarqawi established a working relationship with several other groups in the region and beyond. For instance, an Al Zarqawi cell in the Pankisi Valley in Georgia provided training to North Africans who had been recruited to conduct chemical and biological attacks in France and the U.K. ${ }^{5}$ In preparation for targeting Europe and beyond, training and experiments in building chemical and biological weapons were also conducted in the Khurmal chemical plant and training camp in an area controlled by Ansar Al Islam in the Halabja district of Suleimaniyeh Province in Kurdish Iraq. In addition to groups in Iraq, Al Zarqawi has either absorbed or begun to influence several other networks in Europe. As such, the Salafi Jihad networks influenced or controlled by Al Zarqawi have become the most pressing terrorist threat to the European continent and North America. Due to an excessive focus on Al Qaeda by governments worldwide, other groups, such as the Islamic Group of the Moroccan Combatants (GICM), or new networks, such as those organized by Al Zarqawi, have emerged.

\section{The New Face of Al Qaeda}

In waging global jihad, Al Qaeda plays a specific role. Using its magnified position, it seeks to promote a "clash of civilizations" between the West and Islam. As the proclaimed vanguard of the Islamic movements, Al Qaeda's intermittent attacks on symbolic, strategic, and high-profile targets are intended to inspire and instigate both Islamists and the wider Muslim community to enter into perpetual conflict with the West. After Al Qaeda attacked America's most iconic targets on 9/11, the group had achieved its primary aim. Both the September 11 attacks and the U.S. response mobi-

4 European intelligence services monitored Said Mansour, a Moroccan living in Denmark, facilitating the introductions between Maqdisi and Abu Qatada.

5 Interview with Investigative Judge Jean-Louis Bruguiere, February 2004. 
lized over thirty violent Islamist groups into periodically attacking the United States or its allies and friends.

With the events of $9 / 11$, both the frequency and scale of the threats posed by terrorist groups dramatically changed. Prior to September 2001, terrorism was perceived as a public nuisance and a law and order problem. After that date, terrorism was a national security issue. Due to the potential for mass destruction and mass disruption, terrorism remains on top of the national agenda, or is at least on the political agenda, of the targeted states. In order of priority, most national security agencies place terrorism first, followed by organized crime, and then proliferation of weapons of mass destruction.

\section{Threats Beyond Al Qaeda}

Although governments continue to focus on $\mathrm{Al}$ Qaeda as a group, the real terrorist threat is now embodied by the Al Qaeda network, or movement. Since 9/11, the bulk of the terrorist attacks that have been carried out around the world have not been conducted by Al Qaeda, but by its associated groups, such as Jemmah Islamiyah, Ansar Al Islam, the Al Zarqawi group, Salafi Group for Call and Combat, Abu Sayyaf, Special Purpose Islamic Regiment, Islamic International Brigade, Riyudes-Salikhin Reconnaissance and Sabotage Battalion of Chechen Martyrs, Lashkar-e-Toiba, Jayash-e-Muhammad, etc. Many of these groups were indoctrinated, armed, trained, and financed by Al Qaeda or the Taliban in Afghanistan and other conflict zones throughout the 1990s.

Today, Al Qaeda has lost operational control of many of the groups it assisted when Afghanistan was a terrorist Disneyland from February 1989, after the Soviets withdrew, until the U.S.-led intervention in October 2001. Despite Al Qaeda's loss of command with the disruption of its Afghan haven, the associated Islamist groups of $\mathrm{Al}$ Qaeda continue to use the ideological and logistical infrastructure built by Al Qaeda during the last decade. In addition to possessing both increased motivation and capabilities to attack the West, violent Islamists are determined to target Middle Eastern regimes they perceive as un-Islamic. Islamist strength is growing in Saudi Arabia and Yemen, the two countries that have produced the largest number of Al Qaeda members. On average, pre-9/11 Saudi Arabia witnessed one terrorist attack each year. Since the U.S. invasion of Iraq in March 2003, Saudi Arabia has experienced a terrorist encounter or attack every month.

\section{Ideological, Logistical, and Operational Linkages}

Al Qaeda interfaces with a number of Islamist groups around the world at the local level. As a direct result of this relationship, these local groups are becoming increasingly violent, and some are becoming as violent as Al Qaeda. There are marked differences in ideology and strategy between these disparate Islamist groups, but many of them feed off each other and-more importantly-learn from one another. Al Zarqawi wanted to target the Shia Muslims in Iraq in order to create a civil war within Iraq, but Bin Laden always campaigned for an inclusive rather than an exclusive policy. Nonetheless, Al Qaeda, and especially Bin Laden, is still held in respect and awe by many 
Muslims working for and with Zarqawi. Faraj Ahmad Najmuddin (a.k.a. Saleh Krekar, Abu Sayed Fateh, Fateh Krekar, and Mullah Krekar), the founder of Ansar Al Islam who is currently living in Norway, said in 2000 that Bin Laden represented the crown of the Islamic nation. Ansar Al Islam was established by the merger of Jund Al Islam (Soldiers of Islam) and the Islamic Unity Movement, a faction of the Islamic Movement of Iraqi Kurdistan. ${ }^{6}$

The late Ibn ul-Khattab, the long-time commander of the Islamic International Brigade in Chechnya, described Osama bin Laden as "one of the major scholars of jihad, as well as being a main commander of the mujahidin worldwide." Khattab added:

The West, and the rest of the world, are accusing Osama bin Laden of being the primary sponsor and organizer of what they call 'international terrorism' today. But as far as we are concerned, he is our brother in Islam. He is someone with knowledge and a mujahid fighting with his wealth and his self for the sake of Allah. He is a sincere brother and he is completely opposite to what the disbelievers are accusing him of. We know that he is well established with the mujahidin in Afghanistan and other places in the world. What the Americans are saying is not true. However, it is an obligation for all Muslims to help each other in order to promote the religion of Islam.... He fought for many years against the communists and is now engaged in a war against American imperialism. ${ }^{7}$

The penetration of local and regional conflicts by transnational Islamist groups such as Al Zarqawi's network and Jemmah Islamiyah has given more local extremist groups new capabilities, and has increased the staying power of the transnational organizations. Until recently, many in the West perceived the conflict in Chechnya not as an Islamist campaign but as a separatist movement. Even now, many Western governments permit Chechen groups to disseminate propaganda, raise funds, and procure supplies on Western soil. Similarly, Kashmir, Algeria, Mindanao in the Philippines, Iraq, and other conflict zones have been effectively penetrated by Al Qaeda and other transnational networks. Little did governments realize that, after the loss of their bases in Afghanistan, Islamists would simply migrate to these conflict zones to compensate for the destruction of their Afghan facilities.

Today it is difficult to completely separate some of the regional conflicts, which have local grievances and indigenous roots, from the movement of global jihad. Local conflict zones - from the Philippines, to Kashmir, to Yemen, to Somalia, to Algeriahave been used by Al Qaeda and its associated groups. For instance, Al Qaeda influenced the Southeast Asian groups with their ideology of attacking not only their local governments but also the United States and its allies. After Al Qaeda supported these smaller Southeast Asian organizations with training, funding, and ideology, some are beginning to behave like Al Qaeda. After Jemmah Islamiyah (JI) started to work with Al Qaeda, the leader of JI in Singapore, Ma Salamat Kasthari, began plotting to hijack

6 Among the $\mathrm{CNN}$ recoveries from the Al Qaeda registry in Afghanistan, I have identified and examined two videotapes by the Islamic Movement of Iraqi Kurdistan.

7 Ibn-ul-Khattab, Europe: We are still at the beginning of Jihad in this Region (London: Azzam Publications, 27 September 1999). 
an Aeroflot aircraft from Bangkok, Thailand, and crash it into the Changi International Airport in Singapore. This is clearly an instance of an Al Qaeda tactic being adopted by a local Southeast Asian group. Many local Islamist groups never even considered the tactics of mass casualty attacks against Western targets or suicide attacks until Al Qaeda began to exert an influence over them.

\section{Understanding the Challenge}

Since the U.S.-led intervention began in Afghanistan on 7 October 2001, Al Qaeda and its affiliated groups have successfully sought and generated wider support for its campaign against the U.S. and its allies. Although not organized by Al Qaeda, there were worldwide demonstrations immediately after the initial U.S. and U.K. air strikes from heavy bombers, and after U.S. Navy aircraft and Tomahawk cruise missiles struck targets near Kabul, Kandahar, and Jalalabad. To attract recruits and support, Al Qaeda and its associate groups continue to build confidence among Islamic youth, stressing the impressive record of the Islamists. During the last two decades, Islamist extremists successfully fought the Soviet Union and the Northern Alliance (primarily backed by Russia) in Afghanistan, the Russians in Chechnya, and the coalition troops in Iraq. In Islamist literature and propaganda, "holy war by the brothers against the infidel West" is presented as a continuation of a Muslim's duty. The decade-long anti-Soviet Afghan campaign culminated in the collapse of the Soviet Empire and the end of the Cold War. Al Qaeda and its associated groups present Islamism as a political ideology that can fight against - and defeat - yet another superpower.

Although the heavy bombing disrupted and degraded the physical infrastructure of Al Qaeda and the Taliban in Afghanistan, ${ }^{8}$ segments of the Muslim territorial and emigrant communities from Australia to the Middle East and Canada provide recruits and funding that have somewhat cushioned the loss. ${ }^{9}$ The future survival of Islamist networks will depend on the continuing appeal of their radical ideology that thus far has proven capable of sustaining a fledgling global support network. In the virtual absence of counter-propaganda, both literate and illiterate Muslims view the ideology of global jihad as compatible with Islamic theology.

To counter the ideological appeal of the Islamists, the anti-terrorist coalition needs both a strategic vision and tactical direction. The anti-terrorist coalition currently lacks the capacity to counter Al Qaeda's broad strategy, as formulated by Ayman Al-Zawahiri, Bin Laden's principal strategist. In his last will, titled "The Knights Under the Prophets Banner," Al Zawahiri charted the future direction of the Islamist movement. ${ }^{10}$ As the U.S. builds its multinational coalition and deploys its troops in Afghanistan, the

8 Philip Smucker, “Al Qaeda's Greatest Escape: The Military and the Media on Terror's Trial” (Washington, D.C.: Brassey's, 2004). Smucker's account provides operational details of Al Qaeda's great escape against the backdrop of the U.S.-led coalition intervention.

9 Michael Isikoff, "9-11 Hijackers: A Saudi Money Trail: The Feds Probe a Possible New Saudi Link to Al Qaeda," Newsweek, 22 November 2002.

10 Ayman Al Zawahiri, “The Knights Under the Prophet's Banner," Internet version in English, released in November 2001; made available by Al-Sharq al-Awsat, 2 December 2001. 
Philippines, Yemen, and Georgia, Islamists are continuously building multinational alliances of terrorist groups from the Far East to the Caucasus. Advancing the concept of the universality of the battle, Al Zawahiri has successfully widened the conflict from the national or regional to the global arena. Al Zawahiri sought to counter U.S. initiatives by expanding Al Qaeda's existing alliance, made up of the "jihad movements in the various lands of Islam as well as [Afghanistan and Chechnya] that have been liberated in the name of jihad for the sake of God."11 To quote Al Zawahiri, the alliance represents a

growing power that is rallying under the banner of jihad for the sake of God and operating outside the scope of the new world order. It is free of servitude to the dominating western empire. It promises destruction and ruin for the new Crusades against the lands of Islam. It is ready for revenge against the heads of the world's gathering of infidels, the United States, Russia, and Israel. It is anxious to seek retribution for the blood of the martyrs, the grief of the mothers, the deprivation of the orphans, the suffering of the detainees, and the sores of the tortured people throughout the land of Islam, from Eastern Turkestan to Andalusia [the Muslim state in Spain]. ${ }^{12}$

In an effort to mobilize the "Muslim nation," Al Qaeda projected the confrontation in Afghanistan as a battle between "Islam against infidelity." Reviewing the lack of support by Islamist movements immediately after 9/11, Al Qaeda emphasized the need for perseverance, patience, steadfastness, and adherence to a firm set of principles. In keeping with the belief that the key to victory is the example set by the movement's leadership, Al Qaeda placed the responsibility for the campaign on the leaders, and the responsibility for the quality of their leadership on the membership. To the words of the Koran, "O ye who believe. Endure, outdo all others in endurance, be ready, and observe your duty to Allah, in order that ye may succeed." Al Zawahiri adds,

[i]f signs of relaxation and retreat start to show on the leadership, the movement must find ways to straighten out its leadership and not to permit it to deviate from the line of jihad. The loyalty to the leadership and the acknowledgement of its precedence and merit represent a duty that must be emphasized and a value that must be consolidated. But if loyalty to the leadership reaches the point of declaring it holy, and if the acknowledgement of its precedence and merit leads to infallibility, the movement will suffer from methodological blindness. Any leadership flaw could lead to a historic catastrophe, not only for the movement but also for the entire nation. Hence comes the importance of the issue of leadership in Islamic action in general and jihad action in particular, and the nation's need for a scientific, struggling, and rational leadership that could guide the nation, amidst the mighty storms and hurricanes, toward its goal with awareness and prudence, without losing sight of its path, stumbling aimlessly, or reversing its course. ${ }^{13}$

11 Ayman Al Zawahiri, "Knights Under the Prophet's Banner-Meditations on the Jihadist Movement," Al-Sharq al-Awsat (in Arabic), London, 2 December 2001.

Ibid.

13 Ibid. 
Al Zawahiri justifies an escalation in the methods of strikes and tools of resistance by patiently stressing four points in his post 9/11 book, Knights Under the Prophet's Banner-Meditations on the Jihadist Movement. ${ }^{14}$ First, he emphasizes the need to inflict maximum casualties against the opponent, for this is the language understood by the West, no matter how much time and effort such operations take. Second, Al Zawahiri stressed the need to concentrate on martyrdom (suicide) operations as the most successful way of inflicting damage against the enemies of Islam and the least costly to the mujahedeen in terms of casualties. Third, he required that the targets as well as the type and method of weapons used be chosen with a view to having an impact on the structure of the enemy, an impact sufficient to stop its "brutality, arrogance, and disregard for all taboos and customs." Fourth, Al Zawahiri stressed that a focus on "the domestic enemy alone will not be feasible at this stage," meaning that local Islamist groups must strike not only domestic but also foreign targets, both on their own soil and overseas.

Considering the limitations under which Al Qaeda operates, its post-Taliban exhortations urge Islamist groups other than $\mathrm{Al}$ Qaeda to engage in mass casualty terrorism. Aware of the depletion of resources on its side, Al Qaeda has called for a change in the method of strikes and the choice of targets against the superior coalition forces to "keep up with the tremendous increase in the number of its enemies, the quality of their weapons, their destructive powers, their disregard for all taboos, and disrespect for the customs of wars and conflicts." 15 Al Qaeda significantly increased the popularity of suicide terrorism - a time-tested tactic for killing, maiming, and injuring opponents in substantial numbers - by launching the first Islamist suicide attack on Western soil. In a pre-recorded Al Qaeda video message, the UA93 hijacker Ahmed Ibrahim Al Haznawi (who planned to target the U.S. Capitol) proclaimed: "The time of humiliation and subjugation is over.... But, today we are killing them in the midst of their homes. It's time to kill Americans in their heartland." 16

As most Islamist groups are territorially bound, they are unlikely to follow Al Qaeda's exhortation. Nonetheless, Al Qaeda sleeper cells located in Europe and the U.S.- - both newly formed cells and cells introduced from overseas - are likely to strike targets on Western soil. As a priority, Al Qaeda has called to shift the campaign to the continental U.S. However, unprecedented law enforcement and intelligence cooperation, the intensified hunt for Al Qaeda cells, and the increased level of public vigilance in European and North American countries has made it difficult for terrorists to mount

14 Ibid.

15 Ibid. Because coalition forces attacked during Ramadan, Al Qaeda said that the "enemy" has a "disregard for all taboos, and disrespect for the customs of wars and conflicts."

16 "The Wills of the New York and Washington Battle Martyrs," Al Qaeda video, where Al Zawahiri takes credit for the 9/11 attacks with footage of a confession by Ahmed Ibrahim alHaznawi, one of the hijackers of UA 93 that crashed in Pennsylvania, pleading with God to accept him as a martyr, against the backdrop of a montage of the WTC on flames. Clip released by Al Jazeera to Western networks on 15 April 2002; complete film telecast on Al Jazeera on 18 April 2002. 
operations in these states. Nonetheless, conventional deterrence-capture, arrest, trial, imprisonment, humiliation, and injury or execution - of terrorists is unlikely to permanently protect the West from terrorism. As long as the operational, logistical, and ideological infrastructures of a terrorist group or network remain intact, terrorism will threaten both the Muslim world and the Western world. As we have seen with the decline of Al Qaeda as a group, the organizations that perpetrate terror are neither invincible nor impervious to destruction. By understanding the operational and ideological techniques of $\mathrm{Al}$ Qaeda and its affiliated groups, counter-measures can be developed to disrupt, degrade and destroy them. By painstakingly detecting the worldwide physical infrastructure and human networks of extremist Islamists, their organizations can be dismantled and their leading figures incapacitated. However, can the long-term strategic threat posed by violent Islamists be neutralized by military means alone?

By means of comparison, Islamist organizations of the past fizzled out because they did not have battle-tested structures. Previously, Islamists relied on village, clan, and tribe-centered organizations based on traditional loyalties. The Islamists of the twentieth century lacked a modern, robust, resilient organizational structure. By adapting preexisting models and seamlessly adjusting them to modern requirements, post-modern Islamists have built organizations that are flexible and dynamic. Al Qaeda's politically clandestine structure is built on the idea of internationalism. Using techniques drawn from Leninism and operating on the Marxist militant model, Al Qaeda and its associate groups use battle names, adhere strictly to a cell structure, follow the idea of a cadre party, maintain tight discipline, promote self-sacrifice and reverence for the leadership, and are guided by a program of action. ${ }^{17} \mathrm{Al}$ Qaeda and its allies are self-reproducing. and therefore hard to defeat. As there is no historical precedent to Al Qaeda or its networks, the past offers very little guidance. The success or failure of the U.S.-led antiterrorist campaign will depend on the ability and willingness of the U.S. and its coalition partners to learn as they proceed. In an ever-changing dynamic environment, only by minimizing failures and maximizing successes can they prevail against a determined enemy that is willing to die as well as kill. Specialists in counter-revolutionary warfare and counter-terrorism lack a plan and a model to fight Al Qaeda and its affiliates, who together constitute the premier global terrorist network. In the Bush or Blair cabinets, there is no equivalent to Ayman $\mathrm{Al}$ Zawahiri, a strategist with a vision and a mission.

\section{Threat and Response Cycles}

The threat of terrorism has steadily escalated since the end of the Cold War. In the years that followed the fall of the Berlin Wall, state sponsors lost control over nonstate armed actors. An ideological vacuum resulted, and with the confrontation between the U.S. and the USSR coming to an end, the black and gray markets were flooded with vast quantities of conventional and unconventional weapons. Furthermore, the increased pace of globalization heralded an era of inexpensive travel and communication. Both within and outside the world's conflict zones, terrorist groups

17 For red models, see Noemi Gal-Or, Revolutionary Terrorism, Encyclopedia of Terrorism, Volume 1, 194-96. 
developed front, cover, and sympathetic organizations to take advantage of the forces of globalization. These organizations, taking the guise of human rights, humanitarian, commercial, economic, social, cultural, media, labor, recreational, political, religious, and other community bodies were able and willing to exploit both their communities and other resources. Due to the sustained suppression of terrorist groups and their support bases in the global south of Asia, Africa, the Middle East, and Latin America, many members and supporters of terror groups moved to the West.

Exploiting the liberal values of the West, foreign terrorist groups created vast support networks on Western soil that funded terror campaigns from Algeria to Sri Lanka. Terrorists even tapped into grants or aid given by Western countries. Following the Cold War practice of monitoring spies, Western governments monitored terrorist groups operating in their countries, but did little to erode their strength. Until $9 / 11$, most foreign terror groups used the West for refuge and support activity and not to conduct terrorist attacks against Western states. Many Western governments - notably Canada, Australia, and New Zealand-observed the support activities these groups conducted, but took no action. After 9/11, with the sustained call by Osama bin Laden that it was "the duty of the Muslims to wage jihad," many support cells have been transformed into attack cells.

Since the East Africa embassy bombings of August 1998, the threat of a mass casualty attack in the U.S. had been apparent, but Washington lacked sufficient domestic or international support to intervene in Afghanistan. With the Soviet withdrawal in February 1989, Afghanistan replaced the Syrian-controlled Bekaa Valley in Lebanon as the world's premier terrorist training center for about forty guerrilla and terrorist groups. With no vital interests at stake in this remote corner of Asia, the West was oblivious to the suffering of the Afghan people, who had endured death and destruction for two decades. Human civilization progressed in many directions in the last century, but like a shadow, the conflicts it neglected and ignored are returning with a vengeance. With the continuing international neglect of Afghanistan, the global center of gravity of terrorism gradually shifted to Afghanistan throughout the 1990s. Although terrorist groups consistently grew in strength, size, and influence throughout the 1990s, governments failed to understand the developments on the ground. For instance, the lead U.S. law enforcement agency, the Federal Bureau of Investigation, had placed organized crime above terrorism on its list of priorities. Similarly, the U.S. Central Intelligence Agency closed down a number of its overseas monitoring stations, and did not invest adequately in agent placement or recruitment operations.

A multitude of other factors also helped create the conditions that allowed 9/11 to happen: U.S. disengagement from world affairs; the Western myth that controlling its borders will protect itself from the rest of the world; international neglect of protracted conflicts, etc. Traditionally, the development of counter-measures has been a reaction to a breach of security. European governments, for instance, developed elite forces to combat terrorism in response to Germany's failure to prevent the Palestinian Liberation Organization's massacre of Israeli athletes at the Munich Olympic Games in Septem- 
ber of $1972 .^{18}$ Thirty years later, the primary locus of international terrorism had shifted from the Middle East to Asia, but terrorist groups could still conduct long-range deep penetration operations to strike the West. The horror, fear, and anger generated by the September 11 attacks spurred unprecedented levels of security, intelligence, and judicial cooperation worldwide. To combat Bin Laden's alliance, the World Islamic Front for Jihad Against Crusaders and Jews, the international community has belatedly formed an anti-terrorist coalition. At the heart of the Islamist alliance is the ideology of global jihad articulated by Al Qaeda and its associates. At the core of the counter-terrorist coalition are the Western and Asian liberal democracies-North America, Europe, Australia, and Japan - the wealthiest and most powerful governments that can sustain a protracted campaign against terrorism in the years ahead.

In international politics, the West is the leader. It leads the international community, it sets the standards, and in many cases it provides the resources. Until September 2001, both the extant and the emerging terrorist threats were poorly understood. As Afghanistan gradually turned into a terrorist haven, the world looked the other way; Western and other governments failed to forecast probable future developments. Until 9/11, the Western response to terrorism had been reactive. The Western mindset was that of a fisherman instead of a hunter. In the fisherman model, government enforcement authorities wait to respond until an attack occurs. Many government agencies had to wait for a lead to start an investigation; counter-terrorism operations were leaddriven and not intelligence-driven. Following the hunter metaphor, after 9/11, government enforcement bodies, working closely with their intelligence counterparts, proactively targeted terrorist cells engaged in planning and preparing operations. The U.S. mindset was forced to change after 9/11, and the European mindset after 3/11 - the Madrid train bombing. Unfortunately, in order for countries to develop robust measures, their governments and societies had to first be affected by terrorism. Otherwise, legislation had no public support, and politicians lacked the courage to do what was necessary to combat terrorism.

As the counter-terrorism response model that would be emulated by the rest of the world, the Western response had to be right. The West was regarded as the standard bearer in this regard. For instance, elite counter-terrorism units were created only after the Munich Olympics in 1972. After the German police failed to counter the attack by the Black September Organization (a faction of Fatah, the military wing of the PLO) and their taking of Israeli hostages, the German government created GSG9, and the French government soon thereafter created GIGN. Other governments, including Italy, Spain, and countries outside Europe, followed suit. The West was resourceful; as such, it had greater staying power in the counter-terrorist struggle. In conflict zones such as Bosnia and Herzegovina, the Euro-Atlantic Alliance, NATO, is committed to a longterm presence. Similarly, the West had technological superiority; its technical intelli-

${ }_{18}$ Bruce Hoffman, Inside Terrorism (London: Victor Gollancz, 1998); 124, and Paul Wilkinson, Terrorism Versus Democracy: The Liberal State's Response (London: Frank Cass, 2001), 190. 
gence agencies had global coverage and collected the largest volume of intelligence. ${ }^{19}$ Until the West develops an appropriate model to fight terrorism, the rest of the world will lack the leadership and the commitment to do so on their own part.

\section{Problems of Response}

To sustain campaigns of politically motivated violence (insurgency, terrorism, guerrilla warfare, assassination, sabotage, ethnocide), their proponents and perpetrators build support networks as well as operational networks. While support networks generate financing and help recruit members, operational networks prepare and execute attacks. When fighting terrorism, it is essential that both governments and their publics understand that operational cells cannot survive without support cells. When responding to terrorism, therefore, government must engage and neutralize both the terror group itself and its support base to a point where the organization becomes operationally ineffective. Usually, the range of measures necessary to operationally shut down an organization includes neutralizing the leadership and simultaneously dampening public support to ensure that the group does not revive. The approaches target both the terrorist group - especially the top tier of leadership - and the support base. Since extremist ideology and support networks ensure the survival of the group, targeting these components is critical. The intelligence community, military forces, and law enforcement agencies alone cannot combat terrorism and extremism.

In a terrorist support network, propaganda is the key to recruitment and generation of support. Terrorists enjoy disproportionately vast support networks. For instance, Muhammed Mansour Jabarah, a Canadian who was assigned to coordinate the Al Qaeda attacks in Southeast Asia, was recruited by Sulaiman Abu Gaith, a Kuwaiti, who showed him

propaganda videos about the war in Chechnya and told him about Abdullah Azzam, one of the founders of extremist Islamist philosophy. Jabarah returned to Canada, but his heart was already with jihad.... Jabarah began raising money in southern Ontario for the Islamic fighters in Chechnya, which he sent to Abu Gaith. ... Abu Gaith released a videotaped statement in which he called the $9 / 11$ attacks 'a good deed ... the Americans should know that the storm of plane attacks will not abate, with God's permission. There are thousands of the Islamic nation's youth who are eager to die just as the Americans are eager to live. ${ }^{20}$

However, governments tolerate terrorist support networks, as they pose no direct and immediate threat. Furthermore, most Western liberal democracies, such as Canada, as well as emerging democracies-governments in the global south that seek to emulate the West - tolerate terrorist propaganda.

19 Rohan Gunaratna, "The Terrorist Threat to the Continent," presentation at a meeting of the Special Committee of NATO, Ministry of Foreign Affairs, Copenhagen, 27 May 2004.

20 Stewart Bell, Cold Terror: How Canada Nurtures and Exports Terrorism Around the World (Toronto: John Wiley \& Sons, 2004), 194-95. 


\section{The Internet as a Primary Communication Tool}

To a large extent, counter-terrorism policies, structures, and practices have developed during the last thirty years to fight terrorist operational cells, not support cells. But, since terrorists are like sharks that rapidly move in search of fresh opportunities, they are exploiting the Internet as a new domain. Despite the Internet's status as the principal method by which the post-9/11 terrorist ideologues indoctrinate new recruits, the legislation to target terrorist and extremist Web sites is still in its infancy. In addition to reinforcing their belief system, Islamists use the "Internet for five primary purposes: propaganda, recruitment, indoctrination, fund-raising, [and] psychological warfare." The Internet provides terrorist organizations and their support bases

easy access, little or no regulation, censorship, or other forms of government control, potentially huge audiences spread throughout the world, anonymity of communication, fast flow of information, inexpensive development and maintenance of a Web presence, a multimedia environment (the ability to combine text, graphics, audio, and video, and to allow users to download films, songs, books, posters and so forth), and the ability to shape coverage in the traditional mass media, which increasingly use the internet as a source for stories. ${ }^{22}$

Exemplifying how the Internet has been used as a platform for politicizing, radicalizing, and mobilizing terrorist support activity, an analyst states: "Potential recruits are bombarded with religious decrees and anti-American propaganda, provided with training manuals on how to be a terrorist, and - as they are led through a maze of secret chat rooms - given specific instructions on how to make the journey to Iraq." ${ }^{23}$ In one particularly graphic exchange in a secret Al Qaeda chat room in early September 2003, an unknown Islamist user, with the user name "Redemption is Close," wrote, "Brothers, how do I go to Iraq for Jihad? Are there any army camps and is there someone who commands there?" Four days later he received a reply from "Merciless Terrorist": "Dear Brother, the road is wide open for you - there are many groups, go out for someone you trust, he will be the protector of the Iraqi regions and with the help of Allah you will become one of the mujahidin., 24

U.S. Web sites, chat rooms, and discussion groups were used by U.S.-based support cells to target American interests. For instance, a posting on Yahoo!QoqazGroup on 25 February 2003 called upon Muslims who work for the American military to disclose targeting information to the mujahedeen. In the urgent appeal, the requested targets included the locations of American military personnel, logistics support, and weaponry, as well as the location of American oil interests and the routes of ships serving those interests. The poster of this message was "Abu Banan," a frequent poster

${ }^{21}$ Madeleine Gruen, "White Ethnonationalist and Political Islamist Methods of Fund-raising and Propaganda on the Internet," in The Changing Face of Terrorism, ed. Rohan Gunaratna (Singapore: Eastern Universities Press, 2004), 127.

${ }^{22}$ Gabriel Weimann, "www.terror.net: How Modern Terrorism Uses the Internet," United States Institute of Peace Publication No. 116 (March 2004), 13.

Weimann, "www.terror.net," 13.

24 Ibid., 8-9. 
to the discussion group. Such information, if it were provided, could lead to significant fatalities and casualties among American and allied troops. Similarly, a member of the same discussion group, Khalid Jbaihi, another frequent poster, provided a detailed response to a specific request for information on how one could go train for jihad in a Laskar-e-Toiba training camp in Pakistan. Beginning October 2001, the U.S.-led global coalition dismantled the training camps of Al Qaeda and several other Islamist groups in Afghanistan. To partially compensate for this loss, alternative camps were established in Pakistan, where Laskar-e-Toiba, a group affiliated with Al Qaeda, provided training. At the time that Khalid Jbaihi made these frequent postings to Yahoo!QoqazGroup, the FBI notes that he was a computer science student at New Mexico State University in the U.S.

Saudi doctoral candidate Samy Omar Al-Hussayen of Moscow, Idaho, frequented multiple electronic platforms in pursuit of jihad. ${ }^{25}$ Al-Hussayen promoted ${ }^{26}$ Sheikh Salman Al-Ouda and Sheikh Safar Al-Hawali, the two Saudi sheiks associated with Al Qaeda, ${ }^{27}$ and its leader Osama bin Laden. ${ }^{28}$ In addition to evidence of having provided support for two campaigns, in Palestine and Chechnya, ${ }^{29}$ the FBI recovered Hamas fund-raising literature and images of Ibn-ul-Khattab ${ }^{30}$ and Shamil Basayev ${ }^{31}$ from Al-

25 The overwhelming evidence of Al-Hussayen's role is based on files recovered from Al-Hussayen's home computer; FISA intercepts; records obtained from OLM; files recovered from the service providers Interland and Yahoo; files obtained from Internet archives for Web sites; and documents seized during the search of Al-Hussayen's home. I examined the contents of two of the twenty-one computers seized by the FBI. FISA intercept [B67a], 15 January 2003.

27 "Bombing Saudi Arabia, National Guard Facility Riyah [sic], Saudi Arabia on 11/13/95," Telex from FBI Atlanta to Director FBI; based on fax received by CNN Atlanta at 11.36 PM on 14 November 1995; Operation "Blessed Kaaba" and Operation "Aqsa Mosque," In the Name of God, the Magnificent the merciful, Statement Number (2) and (3) respectively, The Islamic Army for the Liberation of Holy Places, n.d. n.p.; The Formation of the Islamic Army for the Liberation of the Holy Places, In the Name of God, the Magnificent the merciful, Statement Number (1), The Islamic Army for the Liberation of Holy Places, n.d. n.p. All the documents were provided by the U.S. Department of Justice.

Both directly and through $\mathrm{Al}$ Qaeda fronts, Osama bin Laden repeatedly publicized the views of these two Saudi sheiks and called for their release from Saudi custody. Furthermore, the U.S. and other governments recovered substantial information and propaganda produced by these two men in Afghanistan and Pakistan, especially that of Al-Ouda. The recoveries included audiotapes of Al-Ouda and one CD bearing Al-Ouda's name, and an English synopsis recovered from a suspected Al Qaeda safe house in Islamabad, Pakistan; IB96 and Afghanistan Tracking Number AFGP-2002-803723. Two cassette tapes of Al-Ouda found in the former home of Osama bin Laden in Kandahar City, Afghanistan, labeled AFGP-2002801184. File obtained from the service provider Interland on 13 October 2000; file obtained from AlHussayen's home computer on 10 November 2000; file obtained from Yahoo!, 9 February 2000; and file recovered from Al-Hussayen's home computer, 15 June 2000.

31 File obtained from Yahoo!, 11 February 2000. 
Hussayen's computer. Furthermore, Al-Hussayen distributed articles, interviews, broadcasts, and fatwa (legal decrees) calling for and justifying suicide bombings. ${ }^{32}$

Terrorist ideologues and their supporters use the World Wide Web and books to disseminate information and misinformation in their campaign to politicize and radicalize Muslims against the West. Before plotting the bombing of two night clubs in Bali, where 202 people were killed, the Al Qaeda strategist Imam Samudra claimed that "to understand jihad" he read a number of books including by Sheikh Safar AlHawali, ${ }^{33}$ Sheikh Salman Al-Ouda, ${ }^{34}$ and number of articles from Internet sites, including "www.Azzam.com, www.qogaz.Net, www.abubaseer.com, www.jehad.net, www.khurasaan.com, www.Azfalrasas.com, www.jihadurspur.net, [and] www.makt habah.net." 35 The case of Imam Samudra illustrates how the terrorist practice of jihad is inspired and instigated by reading the writings of Islamist ideologues in books and on the Internet.

Compared to terrorist operational infrastructures, terrorist support infrastructures have greater staying power. As long as governments are unwilling and unable to target terrorist support and conceptual infrastructures, terrorism will continue to flourish. To challenge the contemporary wave of terrorism, governments must think beyond selfish national interests and traditional military strategy. That is, governments must be prepared to work closely with other governments on a day-to-day basis and develop the critical thinking and new structures to fight both the violence and the extremism that promotes the violence.

\section{From Cooperation to Collaboration}

With the globalization of terrorism throughout the 1990s, the nature, quality, and scale of international cooperation in combating terrorism has changed dramatically. In combating both domestic and international terrorism, the increased coordination in international counter-terrorism efforts has proved to be one of the most important pillars of effective response. The factors driving contemporary international cooperation include the increased reach of terrorist organizations and the severity of the terrorist threat. Due to increased globalization, terrorist groups have been able to operate overseas with relative ease. Many groups have either established support or operational cells in other countries, and some groups cooperate with like-minded groups worldwide. While the $\mathrm{Al}$ Qaeda group has developed a global reach, the $\mathrm{Al}$ Qaeda movement has become the classic example of a terrorist conglomerate.

32 IRS John P. Pulcastro, File 265C-SU-55418-197, FBI Investigation on 11/8/2002 at Spokane, Washington, 19 November 2002.

33 "[Arabic title] (Condemnation of Kissinger), Syaik Dr. Jafar Hawali, which contains data on U.S. brutality and robbery in two Islamic holy places (Haramain)," Imam Samura Police Interview, 16 December 2002.

34 "The fatwa by Syaikh Dr. Salman EAudah concerning the U.S. crimes against the Islamic world (states)," Imam Samudra Police Interview, 16 December 2002.

35 Imam Samudra Police Interview, 16 December 2002. 
In addition to expressing an interest in conducting mass fatality and casualty attacks, terrorist groups are developing their capabilities to conduct mass disruption attacks. ${ }^{36}$ Some groups, such as the Abu Musab Al Zarqawi network, have successfully acquired, developed, and are likely to use chemical, biological, and radiological agents in the immediate future. To those who lived in the belief that terrorists would not kill, maim, injure, and traumatize in large numbers, the events of September 11 provided ample evidence of current and future terrorist intentions.

After 9/11, the scope of matters addressed, the range of actors, and the scale of cooperation changed dramatically. The areas of interaction include security and intelligence, law enforcement, military, judicial, diplomatic, and political cooperation. In addition to the post-war alliance - the Australia-Canada-U.K.-U.S.-New Zealand system-the number of actors cooperating in the fight against terrorism has increased. The civilian and military intelligence agencies of the NATO countries - the largest collectors of counter-terrorism intelligence - are working together with countries outside North America and Europe to combat terrorism. Despite past and present ideological differences, Russia and China have cooperated with the United States. Except Egypt, which has bilateral ties with governments in NATO, the Mediterranean countries - including Mauritania, Morocco, Algeria, Jordan, and Israel-have become dialogue partners with Europe and North America. Even Libya, Sudan, and Iran, former active sponsors of terrorism, have provided information to the U.S. and to other states. For instance, in the case of the Abu Musab Al Zarqawi network, Iran cooperated with Jordan. Although Syria remains designated as a state sponsor of terrorism, Damascus has selectively cooperated with the U.S. on occasion.

With respect to Al Qaeda and its associates, the U.S. government is cooperating with 120 countries, and Britain is cooperating with nearly 100 countries; similarly, Pakistan is cooperating with 70 countries. Still, the bulk of the collaboration-and the bulk of the operational work - is carried out between the Anglo-Saxon countries, followed by third country partnerships: New Zealand with Singapore, Australia with New Zealand, U.S. with Israel, U.S. with Pakistan, U.K. with India, etc. With Middle Eastern and Asian countries providing sound and timely intelligence to the West, the traditional barriers to the West sharing intelligence with the Muslim world have been broken. Despite setbacks, such as the unilateral U.S. invasion of Iraq, its failure to mediate the Israeli-Palestinian conflict, or the Abu Ghraib prison abuse scandal, counter-terrorism cooperation has continued.

Cooperation in counter-terrorism efforts is gradually transforming from coordination to collaboration. Traditionally, security and intelligence services share information on the movement, finances, and weapons of terrorists. As terrorists began to operate across borders, security services coordinated the timing of their counter-terrorist operations. Today, security services are moving from coordinating on operations into collaborating on the targeting of terrorist networks. The areas of collaboration include

${ }^{36}$ Gilbert King, Dirty Bomb: Weapons of Mass Disruption (New York: Chamberlain Bros., 2004). 
exchanges of personnel, joint training, joint and combined operations, sharing of expertise, sharing of experience, transfer of resources, and development of common databases. In addition to security services, law enforcement agencies are building relationships with their counterparts by sharing data, posting their officers overseas, and engaging in joint training and investigations. In addition to the FBI increasing the number of officers posted around the world, state and local law enforcement authorities such as the New York Police Department have posted intelligence officers to Europe, the Middle East, and Asia. On the frontiers of law enforcement cooperation there has been a sea change both in mindset and practice. For instance, instead of case building and successful prosecution, for the first time police officers are being rewarded for turning terrorists and their supporters into informants.

The exchange of information remains at the heart of counter-terrorism collaboration. Traditionally, only heads of services or designated persons exchanged information. Due to the severity of the threat, cooperation today is both formal and informal. Counter-terrorism officials are willing to bypass government rules and regulations to share especially time sensitive intelligence with their counterparts. As a request for a bank account or a phone intercept may take several months or years through the traditional legal channels, officials who realize the threat are willing to dispense with the bureaucracy and informally help their counterparts. In Camps X-ray and Delta, foreign counter-terrorism intelligence officers received access to detainees from their own countries and other foreign countries. In sharing intelligence, it is not the appointment or the rank of the requesting party but "who you know and how well you know that person." ${ }^{, 37}$ The development of such informal connections between intelligence agencies is critical in a security environment where threats take shape rapidly, and where intelligence gathered on one side of the world may only be useful on the other side.

As a function, counter-terrorism intelligence has traditionally fallen within the security services domain. With this work being the sole area of responsibility of these agencies, counter-terrorism intelligence functions have been closely held, and among some services they are still being quite jealously guarded. Nonetheless, in countries that have directly suffered from terrorism, the security and intelligence services have decided to share intelligence among the different agencies - internal, external, civilian, and military - as well as with their law enforcement and military counterparts. For instance, Shin Bet, Israel's internal security service, operates within Israel and in the Occupied Territories in an intelligence capacity and overseas in a security role. Due to the high level of threat Israel faces every day, Shin Bet will share information and work closely with the Israeli military intelligence, a service that works both inside Israel and overseas. On a daily basis, Shin Bet and military intelligence will share intelligence with the Mossad, Israeli's foreign intelligence agency, which is responsible for both collection and covert action overseas. Unfortunately, government agencies begin to cooperate with other agencies even in their own country only if they have directly ex-

37 Interview, Lt.Col. Mike Dolamore, head of the Counter Terrorism School, U.K., December 2002. 
perienced terrorism and perceive that they are under continuous threat. Intra-agency cooperation is crucial to domestic inter-agency cooperation. Domestic interagency cooperation is the building block of international interagency cooperation. With the globalization of terrorism and the rapid development of terrorist networks, governments have no option but to build frameworks for multi-lateral, multi-agency cooperation. ${ }^{38}$ Without developing multi-agency intelligence collection and sharing mechanisms, it will be difficult for current and future governments to target terrorist networks before they strike.

\section{The Principal Actors}

The actors that cooperate in the counter-terrorism arena include security and intelligence services, law enforcement agencies, military forces, judicial bodies, diplomatic offices, and political leaders.

Security and intelligence. The exchange of information between security and intelligence services across the world has been the most established form of cooperation. The Anglo-Saxon and the Western European services have cooperated closely since World War II. Until 9/11, cooperation was largely restricted to the sharing of information on espionage targets. Joint covert action was rare in the 1990s, although an exception was the CIA's cooperation with their Croatian and Egyptian counterparts to capture Fouad Talat Kassim, the operational leader of the Egyptian Islamic Group. Prior to September 2001, the security services in the West rarely collaborated with services outside the West. After 9/11, Western services have been forced to work closely with their Middle Eastern, Asian, and African counterparts on terrorism. As terrorism is increasingly perceived as a common threat, security and intelligence services across the world have collaborated, conducting joint operations against terrorist targets worldwide.

Law enforcement. Traditionally, police, customs, immigration, coast guard, and other law enforcement authorities shared information on criminal matters. Law enforcement agencies shared counter-terrorism responsibilities only when the threat increased. Even INTERPOL and EUROPOL began to focus on terrorism only at the turn of the century. Until 9/11, many law enforcement officers in countries that did not periodically suffer from terrorism firmly believed that counter-terrorism was the responsibility of the security and intelligence community. With the exception of New York and Washington, even today many state and local police departments believe that

38 A real-life example is a case where an Asian intelligence agency may recruit a student traveling to the Middle East to study. A Middle East station of a European intelligence agency, collaborating with the Asian agency, will manage the informant. Another real-life example is how a European agency will recruit a European Muslim and assign him to infiltrate a group of Muslims traveling to Iraq to fight coalition forces. Upon arrival in Iraq, the European Muslim will be arrested by U.S. troops. The informant will be isolated, debriefed by coalition forces on the networks facilitating and the routes used to transport fighters to Iraq, and then either freed to develop an even better understanding of the Iraqi battlefield or transported back to the host country for future operations. 
counter-terrorism is the responsibility of the main American federal law enforcement agency, the FBI. However, where enlightened leaders head up law enforcement efforts, the state and local authorities are beginning to develop counter-terrorism capabilities very similar to those they developed to fight white-collar, violent, and organized crime. A few police departments share with their intelligence counterparts the burden of not only policing and response but also collection and analysis of counter-terrorism intelligence. Rather than relying on a federal authority to collect intelligence in their own state, the involvement of state agencies in everyday collection and analysis has increased the quality of intelligence produced. Any authority or agency is only as good as the extent to which it is in constant contact with developments on the ground: observing and detaining suspected and known terrorists, raiding and seizing their safe houses, interrogating and debriefing detainees, recruiting terrorists, and planting informants in terrorist groups and their support bases. Within federal, state, and local law enforcement authorities, the scale of cooperation has grown particularly on matters pertaining to terrorism.

Military. The failure of the intelligence and law enforcement communities to effectively fight terrorism at home forced the U.S. to deploy its military in a counter-terrorism role. Compared to the very small number of terrorists killed or arrested and successfully prosecuted by the U.S. government on U.S. soil throughout the 1990s, the number of persons who became terrorists grew exponentially overseas. Furthermore, U.S. law enforcement could not effectively conduct operations against Al Qaeda or its host the Taliban without the support of the U.S. military. Al Qaeda's continued use of Afghanistan as a base of operations after September 11 forced the U.S. to deploy its military to dismantle the terrorist training and operational infrastructure in Afghanistan and replace the Taliban regime. As a result of the campaign in Afghanistan, the knowledge of terrorism within coalition military forces has multiplied several times. Prior to 9/11, counter-terrorism was the function of only a few military forces. Even within the Defense Intelligence Agency of the U.S. Department of Defense, or the Defense Intelligence Staff of the U.K.'s Ministry of Defense, the staff dedicated to counter-terrorism functions was under 100. Cooperation in counter-terrorism between the military intelligence agencies was limited in a very few cases, and non-existent in most others. Even within NATO, the post-Cold War focus was on the conventional military threat. Except the Special Committee of NATO (a meeting of heads of security and intelligence services of the Euro-Atlantic area), which focused on espionage until the late 1990s, appreciating and responding to the terrorist threat was not a priority. With the formation of coalitions in Afghanistan and Iraq, Western militaries are sharing counter-terrorism intelligence and conducting joint and combined operations, primarily overseas. As the military is numerically large, law enforcement and intelligence services are tapping into the expertise developed by their military counterparts.

Judicial. With terrorism having become globalized, it became necessary for the ministries and departments of justice of different countries to work together. Many terrorist groups are aware of the difficulties and differences between various criminaljustice and prison systems, and they exploited them to survive and succeed in their operations. As France frequently complained, several violent Islamist groups were oper- 
ating in the U.K., even after 9/11. Likewise, when the PKK was targeted in Germany, it moved its infrastructure to Brussels and to other European cities soft on terrorism. Similarly, several violent Islamist groups found safe haven in the Scandinavian countries, Switzerland, and in Canada. The incompatibility of criminal-justice systems and different legal standards has hindered judicial cooperation over the years. During the post-Cold War period, governments began to harmonize their legislation, mostly on criminal matters. In the post-9/11 environment, most governments prefer rendition to extradition, which involves a lengthy process. Only some governments in Europe-especially the U.K. and Germany-insist on extradition. As the ministries and departments of justice are increasingly involved in counter-terrorism, some have created separate counter-terrorism divisions. Most judicial bodies have belatedly developed the appropriate legislation to fight terrorism. For instance, due to the lack of any applicable law, the Australian government could not detain Abdul Rahim, the Australian Jemmah Islamiyah leader who left Australia one week after JI had killed 88 Australian citizens in Bali, Indonesia. The increased and continuing threat is driving governments to be more committed to developing timely legislation as well as common standards and practices, at least regionally. Nonetheless, even in developed Europe, due to the diverse legal systems on the continent the difficulties are numerous, and progress has been limited.

Diplomatic. The first line of action against foreign terrorist groups operating overseas is diplomacy. For instance, the diplomatic and political tools of government are essential to exert pressure on other governments that actively or tacitly permit the operation of foreign terrorist groups and support bases on their soil. In many ways, the events of 9/11 were a result of continued U.S. failure to persuade Pakistan to intervene in Afghanistan, force the Taliban to abandon Osama bin Laden as an ally, and to shut down the foreign training camps. Although it failed to achieve the desired results, the American and British governments succeeded in persuading Khartoum to expel Bin Laden from Sudan in May 1996. Diplomatic measures supported by economic carrots and military sticks can yield the desired results. Traditionally, foreign offices have cooperated on counter-terrorism, primarily on matters of international law pertaining to terrorism. For instance, foreign ministries and departments of governments have worked closely on developing and implementing international and regional conventions. Furthermore, certain Western governments - notably the United States-have used the diplomatic channel to extended specialist training and other forms of assistance to other states, especially law enforcement agencies in developing countries. In addition to its own academy, the FBI has a separate academy for training foreign law enforcement officers. After $9 / 11$, both the U.S. and some of the major powers have tied both foreign aid and grants to counter-terrorism cooperation. In addition to receiving non-NATO ally status, Pakistan received several hundred million dollars in aid in exchange for working closely with the U.S. in targeting Al Qaeda, the Taliban, and their associates. Many foreign offices have created counter-terrorism divisions, and some foreign offices have even appointed counter-terrorism ambassadors.

Political. With the attacks of September 11, terrorism shifted from a nuisance and a law and order issue into a national security threat. When heads of government and 
state, or even ministers and secretaries of departments and ministries meet, terrorism is placed on their agenda. A new area of cooperation that has emerged after $9 / 11$ is between political leaders. The successful cooperation between George W. Bush and Tony Blair on Iraq facilitated U.K. support for the U.S. invasion of Iraq. Through direct and personalized communication, leaders tend to bypass the lengthy bureaucratic process and make executive decisions and action on behalf of the state. For counter-terrorism initiatives to be effective, the sustained commitment of the nation's political leadership at the highest level is crucial.

\section{Policies, Practices and Procedures}

At the operational level, the success of terrorism depends on secrecy. Similarly, success in the fight against terrorism at an operational level depends on secrecy. Terrorism can be fought at two different levels: tactical and strategic. At a tactical level, to reduce the immediate threat, governments should target the terrorist cells. If the terrorist network is transnational, governments need to share time sensitive, often source-based intelligence with other governments. Unlike during the Cold War, most contemporary terrorist groups have developed transnational networks today. When fighting transnational networks, many operational agencies have developed liaisons with their domestic and foreign counterparts. Counter-terrorism cooperation in sensitive areas such as intelligence has been bilateral between most countries; the U.S. government, for instance, continues to share intelligence with its coalition partners, but in most cases only provides information that pertains to each individual country.

At the strategic level, to change the security and political environment, governments and international organizations can develop domestic legislation, bilateral and regional agreements, and international laws. Such measures take time to materialize, and cannot be conducted in secrecy. Counter-terrorism cooperation has been largely multilateral on judicial matters, especially the twelve United Nations conventions.

The nature of the terrorist threat is such that a government can approach another government, even a state with which it has no diplomatic relations, to enlist its cooperation. Therefore, at the tactical level, cooperation can be ad hoc. To formalize cooperation, a nation may sign a memorandum of understanding with another government. However, in order to change the environment enough to make it hard for a terrorist group to operate, a government - when dealing with a number of governments - can develop agreements. Therefore, at a multilateral level, cooperation can be sustained. The building block of international cooperation is national interagency cooperation. Prior to 9/11, the British intelligence agencies shared less than 5 percent of their intelligence with the British law enforcement authorities. Two years after 9/11, MI5, MI6, and GCHQ share about 30 percent of their intelligence with British law enforcement agencies. At Thames House, the headquarters of MI5, the British government created the Police International Cooperation Unit, headed by a New Scotland Yard officer, to share intelligence with police forces outside the U.K.

For the counter-terrorism policy of a target state to be successful, it must apply its national power throughout the entire life cycle of a terrorist group in order to reduce its 
strength and influence. By using results from conflict observatories, an intelligent government should be able to know when a dispute will break out into violence. A worthwhile investment is to proactively prevent the formation of conflicts by addressing the root causes that spawn violence. Nonetheless, most heads of government and state are not leaders but crisis managers.

As the events in Southern Thailand in early 2004 demonstrated, most governments react to violence after the event. Although members of Puzakha, an Islamist group, raided a government armory and took with them between 300-400 firearms in January 2004, the Thai government did not actively start hunting the raiders to recover the weapons until the members of the group began to mount attacks in Southern Thailand in April 2004. Most governments will leave political unrest to law enforcement until violence becomes a political and public issue.

In the age of post-modern terrorism, the cost of a successful terrorist mega-attack is very high. It affects the nation's image, tourism, investment, travel, etc. As such, the best road to success in fighting the contemporary wave of terrorism is to prevent a terrorist attack, rather than to conduct an "excellent" post-blast investigation, identify and arrest the perpetrators, financiers, facilitators, or supporters. Instead of governments investing billions of dollars in responding to a terrorist attack after it has occurred, it is vastly preferable to prevent terrorist acts before they can take place.

The key to prevention is in training, education, and awareness. In the first phase, it is necessary for governments to train law enforcement officers-especially police, customs, and immigration officers - to be aware of the pre-attack indicators of a terrorist incident. For instance, a police officer who raids an apartment on a tip, or stops a vehicle for speeding, should be trained to look for suspicious indicators that may signal a terrorist attack in the planning and preparation phases. Similarly, an officer on the street - the traffic cop, beat cop, or the police officer at a static or mobile checkpointshould be able to detect, for instance, a suicide bomber. In the second phase, government should invest in public education, increasing public understanding of the threat. By periodically releasing threat information to the public domain, the government can help ensure that the public will be alert. If the government can maintain a state of alertness without alarming the populace, the public will be the eyes and the ears of the state, an extension of the law enforcement machinery.

Intelligence-driven, highly trained tactical counter-terrorism units dedicated to neutralizing terrorist cells planning, preparing, and executing terrorist attacks have proved highly effective. But in most cases, these units lack the intelligence they need to act. As such, in most cases they respond after an event - a kidnapping, a hostage-barricade situation, or a hijacking - and with limited success. As terrorists are increasingly willing to die, responding to an event after the terrorists have taken control of a venue or have hijacked an aircraft or kidnapped an individual may yield limited success. Even if the terrorist attack team is highly trained and experienced, the chance of rescuing the victims may be slim. Furthermore, if the attack team is willing to die, the 
chance of success will be diminished. ${ }^{39}$ Demonstrating the global spread, increasing lethality, and popularity of suicide terrorism as a tactic, from 2000 to 2003, 312 suicide attacks worldwide produced 5354 deaths. ${ }^{40}$ In the Moscow theater siege in October 2002, suicide terrorists from the Islamic International Brigade and the RiyudesSalikhin Reconnaissance and Sabotage Battalion of Chechen Martyrs took 979 hostages. The rescue operation led to the death of 128 persons. ${ }^{41}$

As the precise time and location of an attack is highly unlikely to be available, governments should invest in building informant networks, undercover programs, witness protection programs, and creating a "hunter" mindset among the counter-terrorism community. Only by anticipating threats and committing to a proactive investment aimed at prevention instead of a wasteful reactive approach can governments effectively fight, deter, and reduce the threat of politically motivated violence. Since it is difficult to generate precise intelligence on each and every terrorist operation in the planning and preparation phases, governments should seek to build awareness among both law enforcement officers and the public to detect and disrupt a terrorist operation before it is launched. ${ }^{42}$ Even three years after $9 / 11$, the level of training and retraining of the average police officer is poor. ${ }^{43}$ Less than 5 percent of the police officers in the U.K. have been trained and equipped to respond to a CBRN attack. Therefore, training, educating, and raising the awareness of the counter-terrorism community (intelligence, law enforcement and military personnel) and the public is at the heart of fighting the contemporary wave of terrorism.

\section{New Threshold Terrorism}

Security and intelligence services and law enforcement agencies have thwarted over one hundred terrorist incidents since September 2001. Although conventional terrorist attacks will likely continue to dominate the terrorism landscape, the coming years will witness additional low-probability, high-consequence attacks as well. To remain effective, terrorist masterminds are formulating strategies and tactics of operating below the intelligence radar screen. The likelihood that terrorists will attempt to conduct attacks using chemical, biological, and radiological agents has grown. In March and April 2004, the Jordanian security service foiled a plot that involved a coordinated simultaneous attack on high-profile symbolic and strategic targets in Jordan involving multiple

39 Scott Atran, “Genesis of Suicide Terrorism,” Science 229 (7 March 2003): 1534 (reprint edition).

40 Scott Atran, "Individual Factors in Suicide Terrorism," Science 304 (2 April 2004): 47-49; see www.sciencemag.org/cgi/content/full/304/5667/47/DC1, Table 1.

41 Adam Dolnik \& Richard Pilch, "The Moscow Theater Incident: Perpetrators, Tactics, and the Russian Response," International Negotiation 8:3 (2003).

42 In Israel, 95 percent of suicide attacks are detected and disrupted. Even with the best intelligence network, Israel's military intelligence and internal security agency have been unsuccessful in detecting each and every attack.

43 Nick Allen, "Lack of Training: Terrorist Attacks: We Need More Training - Police," The Scotsman, 15 May 2004. 
chemical-laden vehicles. Had the chemical bombs exploded, they would have killed at least 20,000 people living within a half-mile radius, and maimed and injured another 80,000. A terrorist cell led by Al Zarqawi, the most active terrorist in Iraq, had purchased twenty tons of chemicals and was planning to execute the operation when they were detected.

The attack team Al Ashara, or "The 10," intended to launch a suicide operation against the royal palace, the security services' headquarters, leisure centers frequented by Americans recuperating during military exercises, the Israeli and U.S. Embassies, and other Israeli targets on the Jordan-West Bank border. During the operation to capture members of the terrorist cell, four members were killed. Azmi al-Jayousi, the head of the Jordanian cell, met with Al Zarqawi, first in Afghanistan and then in neighboring Iraq, to plan the bombings. Zarqawi, who has a $\$ 10$ million reward on his head from the U.S. government, gave al-Jayousi about $\$ 170,000$ to buy the chemicals and organize the operation. Another Jordanian, car mechanic Hussein Sharif Hussein, confessed that al-Jayousi had asked him to buy vehicles and modify them so that they could crash through the gates and walls of the targets. Although Zarqawi denied any involvement in the operation in a statement, it is very likely that he was the mastermind.

Conventional terrorist attacks will probably continue to be the most frequent form of attack, but it is very likely that Zarqawi-inspired cells scattered throughout the Middle East and Europe will try to repeat an operation of this scale in the coming years. With the increased difficulty of transporting conventional firearms and explosives to target countries after 9/11, Al Qaeda and its affiliates are moving in a significant way toward using chemical, biological, radiological, and nuclear (CBRN) agents. In addition to developing CBRN sensors for early detection, penetration of terrorist organizations and periodic arrest and debriefing of terrorists could help prevent such attacks. For instance, timely intelligence from Abu Zubaidah, an Al Qaeda detainee, led the U.S. and Pakistani intelligence communities to disrupt a post-9/11 operation by the $\mathrm{Al}$ Qaeda-trained Muslim convert Jose Padilla to use a radiological dispersal device, or "dirty bomb," on U.S. soil (Padilla, a U.S. citizen, was known by the alias Abdullah al Muhajir).

Instead of investing billions of dollars in protection - reflective of a reactive mindset - it is necessary to invest in seeking out the enemy to prevent an attack. The answer to combating new threshold terrorism does not rest only with developing protective suits, detection equipment, vaccines, and antidotes, but in an entire range of measures. They should include a deeper understanding of terrorists' willingness to kill and die. Although terrorist groups' capabilities to mount high-impact attacks have suffered, their intentions to attack have not. The challenge is to target both the physical and conceptual infrastructures of the terrorist organizations. The West is best at tactically going after terrorist cells, not seeking to alter the mindset of terrorists. The Western approach is insufficient to reduce the threat, especially in the middle to long term.

Combating terrorism should be a partnership between the East and the West, rather than a burden to be borne only by the West. Since the bulk of Islamist terrorists originate from the Muslim world, and specifically the Arab world, people from this region 
are perhaps more likely to have the know-how and the tools to successfully counter the terrorist mindset. By working with community and religious leaders, as well as with Arab and Asian Muslim governments, leaders and thinkers should seek to send the message that violent or extreme jihad will only bring misery and pain to Muslims. The West must work with the rest of the world - especially the Muslim world - to ensure that the fight against terrorism is not a clash of civilizations but a contest between moderate and extremist versions of Islam. The West must seek to work closely with moderate Muslim intellectuals and progressive parties in Muslim states. Only by empowering them over the extremist ideologues and the violent groups can the terrorist threat be challenged directly, on its own terms. Without planting seeds of peace in the minds of Muslims, both in the Muslim territorial communities of the Middle East, Africa, and Asia and in expatriate and refugee communities, support for extremism and terrorism will remain and grow.

Muslims in the diaspora and emigrant communities are equally or even more susceptible to supporting and participating in terrorism. To target the conceptual infrastructure of the violent Islamists, it is equally important for Western governmental and non-governmental organizations to work even more closely with Muslim leaders living in Western states. Only by creating a powerful ethic and norm against the use of violence, and building and sustaining a culture of toleration and moderation, can extremism and violence be marginalized.

\section{The Islamist Vision and Mission}

In many respects, the violent Islamists are ahead of their opponents. The most influential terrorist theoretician, Al Zawahiri, who understands both the East and the West, consistently thinks several steps into the future. For instance, immediately after U.S. troops entered Afghanistan, Al Qaeda anticipated how the U.S. would use intergovernmental, governmental, and non-governmental actors to strengthen its position in Afghanistan, especially since the Afghan people had been suffering for two decades. The restoration of normalcy was dependent on the Western powers working with a multitude of other actors. To justify targeting these entities, Al Zawahiri identified the following categories as being Western "tools to fight Islam": 44

- The United Nations;

- Muslim regimes that work with the West;

- Multinational corporations;

- International communications networks;

- Data exchange systems;

- International news agencies;

- Satellite media channels;

44 Ayman Al Zawahiri, "Knights Under the Prophet's Banner - Meditations on the Jihadist Movement," Al-Sharq al-Awsat, in Arabic (London, 2 December 2001). 


\section{- International relief agencies.}

Since Al Zawahiri's call, construction workers, members of the media, and Red Cross personnel have been killed in Afghanistan, aid and relief workers have been murdered in Chechnya, and the UN HQ has been bombed in Iraq. The events in Afghanistan, Chechnya, and Iraq amply demonstrated that Al Zawahiri's edict was being followed. The past three years have also borne witness to Al Zawahiri's claim that, in the face of the anti-terrorist coalition, an alliance made up of the jihad movements in the various "lands of Islam" would arise. This meant that the threat to these agencies would not only come from Al Qaeda, but also from its associated groups located in Asia, the Middle East, Sub-Saharan Africa, and also those operating in the West. An insight into Bin Laden's thinking immediately in the wake of 9/11 informed us that the focus of the next wave of attacks would be on economic targets. He argued that

I say the events that happened on Tuesday 11 September in New York and Washington, that is truly a great event in all measures, and its claims until this moment are not over and are still continuing.... According to their own admissions, the share of the losses on the Wall Street Market reached 16 percent. They said that this number is a record, which has never happened since the opening of the market more than 230 years ago. This large collapse has never happened. The gross amount that is traded in that market reaches 4 trillion dollars. So if we multiply 16 percent with $\$ 4$ trillion to find out the loss that affected the stocks, it reaches $\$ 640$ billion of losses from stocks, with Allah's grace. So this amount, for example, is the budget of Sudan for 640 years. They have lost this, due to an attack that happened with the success of Allah lasting one hour only. The daily income of the American nation is $\$ 20$ billion. The first week they didn't work at all due to the psychological shock of the attack, and even until today some don't work due to the attack. So if you multiply $\$ 20$ billion by one week, it comes out to $\$ 140$ billion, and it is even bigger than this. If you add it to the $\$ 640$ billion, we've reached how much? Approximately $\$ 800$ billion. The cost of the building losses and construction losses? Let us say more than $\$ 30$ billion. Then they have fired or liquidated until today, or a couple of days ago, from the airline companies more than 170,000 employees. That includes cargo plane companies, and commercial airlines, and American studies and analysis have mentioned that 70 percent of the American people even until today still suffer from depression and psychological trauma, after the incident of the two towers, and the attack on the Defense Ministry, the Pentagon - thanks to Allah's grace. One of the well-known American hotel companies, Intercontinental, has fired 20,000 employees - thanks to Allah's grace. Those claims cannot be calculated by anyone due to their very large scale, multitude and complexity - and it is increasing thanks to Allah's grace — so watch as the amount reaches no less than $\$ 1$ trillion by the lowest estimate - thanks to Allah's grace-due to these successful and blessed attacks. We implore Allah to accept those brothers within the ranks of the martyrs, and to admit them to the highest levels of Paradise. ${ }^{45}$

45 Tayseer Allouni [Kabul correspondent of Al-Jazeera], transcript of previously unaired interview with Osama Bin Laden on 21 October 2001. Translated from Arabic by the Institute for Islamic Studies and Research; available at www.alneda.com. 
The next round of attacks - bombings of the Sari and Paddy nightclubs in Bali in October 2002, of the Neptune Paradise Hotel and a chartered aircraft of tourists in Mombasa, Kenya in November 2002, and of a branch office of the Hong Kong Shanghai Banking Corporation in Istanbul in November 2003 in Istanbul-demonstrated the threat international terrorism posed to the economic health of nations around the world. In selecting future targets, violent Islamists will take into account the national economies of its enemies, and the potential economic impact of an attack.

Considering the increased threat that governments pose to Islamist terrorist groups, underground Islamist terrorist groups as well as legitimate political parties will play decisive roles. Instead of Islamist terrorist groups alone shouldering the burden of politicizing, radicalizing, and mobilizing Muslims, Islamist political parties are taking over the duties of propaganda, recruitment, and fundraising. This frees the terrorist groups to concentrate on the planning, preparation, and execution of attacks. The doctrine of Al Qaeda calls upon them to "expose" the "rulers" who fight Islam; to highlight the "importance of loyalty to the faithful and relinquishment of the infidels in the Muslim creed"; to hold "every Muslim responsible for defending Islam, its sanctities, nation, and homeland"; to caution against the "ulama of the sultan and reminding the nation of the virtues of the ulama of jihad and the imams of sacrifice and the need for the nation to defend, protect, honor, and follow them"; and to expose "the extent of aggression against our creed and sanctities and the plundering of our wealth." 46

Preventing Islamists among Muslim diaspora communities in North America, Europe, and Australasia from non-violently advancing their political aims and objectives is difficult. While operating in an environment of tight security and vigilance, $\mathrm{Al}$ Qaeda's post-Iraq strategy is designed for Islamist parties to conceal themselves beneath the veil of legitimate politics and to produce a generation of recruits and supporters to sustain the fight in Iraq. Until favorable conditions emerge, Al Qaeda will operate through mosques, madrasas, community centers, charities, and bookshops in Western Europe and North America.

\section{Afghanistan and Iraq}

The lack of commitment on the part of the international community to the efforts in Afghanistan and Iraq has prevented the creation of state-of-the-art twenty-first-century nation-states in Asia and in the Middle East. Several years after the initial Western intervention in Afghanistan and invasion in Iraq, the security situation on the ground remains tenuous. When the Taliban leader Mullah Muhammad Omar joined forces with Osama Bin Laden in October 2001, the anti-U.S. force multiplied. Similarly, Hezb-iIslami leader Gulbaddin Hekmatiyar joined forces with the Taliban and Al Qaeda. Compared to Al Qaeda, a foreign force, the Taliban and Hezb-i-Islami enjoy signifi-

46 Al Zawahiri, "Knights Under the Prophet's Banner." 
cant support in Afghanistan. ${ }^{47}$ Today, Al Qaeda — essentially an Arab organization-is able to infiltrate, probe, and strike targets because of the linkages it has developed in the Afghan community through its alliance with members of the local Taliban and Hezb-i-Islami forces. The situation would have been very different had Pakistan prevented the Taliban, a regime that was more closely allied to Pakistan than to Al Qaeda, from joining its forces with Al Qaeda. Similarly, without thinking ahead, the U.S. government disbanded the Iraqi army, the only national institution that could have operated effectively across the Sunni, Shia, and Kurdish regions of the country. The shortsighted decision to disband the Iraqi army, a traditional foe of the U.S., has strengthened the insurgents in Iraq and weakened the multinational coalition.

The international outrage following Al Qaeda's multiple attacks on America on 9/11 provided the global community a framework for fighting a multi-headed hydra. Nonetheless, the unilateral U.S. invasion of Iraq has weakened the coalition against terrorism and given a new lease on life to Islamist extremist terror groups worldwide. Despite these initial drawbacks, the U.S., its allies and its friends have learned some valuable lessons. Two successive tiers of Al Qaeda's operational leadership have been virtually obliterated. However, the character of the multigenerational Islamist campaigns ensures the survival of Al Qaeda and its affiliates. The Islamist groups have adapted to the new security environment, replacing its losses and wastage, and continuing the fight. Al Qaeda's interface with Islamist guerrilla and terrorist groups worldwide has prolonged its own life cycle and also re-oriented its counterparts to target the U.S. and its allies. Although the pressure on its leadership in Afghanistan has severed $\mathrm{Al}$ Qaeda's command and control of its vast global terrorist network, the post-Iraq environment has created new and strengthened networks that are exerting influence and control over Al Qaeda's support structures.

${ }^{47}$ It was an unfortunate alliance, and one that could have been disrupted, had the U.S. allowed more time for Pakistan to negotiate with the then Islamic Emirate of Afghanistan to hand over Bin Laden to Islamabad immediately after 9/11. The U.S.-led anti-terrorist coalition initiated its campaign without providing adequate opportunity for diplomatic efforts by Pakistan to drive a wedge between the Taliban and Al Qaeda. The U.S. was looking for a clear and physical target at which to vent its anger and revenge; if they could not have Bin Laden, at least the Taliban seemed like a target with a high enough profile to satisfy the Bush Administration. Although the Taliban and Al Qaeda combined forces in combat against the Northern Alliance, the relationship had its ups and downs. At the request of the Pakistani Inter-Services Intelligence agency (ISI), after the East Africa bombings the Taliban imposed restrictions on Bin Laden's activities, particularly his terrorist operations and press interviews. Although not strictly enforced, these measures led to significant tensions, creating pro- and anti-Bin Laden divisions within the Taliban. Under the leadership of Mullah Omar, the Taliban would not have handed over Bin Laden for trial to a non-Islamic court. However, the Pakistanis could have prevented the formation of the Taliban-Al Qaeda alliance. Had the U.S. intelligence community developed an accurate assessment of the relative numerical strengths of Al Qaeda and the Taliban, and had it understood the implications of unity between a relatively unpopular Al Qaeda and a popular Taliban, it could have avoided the air strikes. 
After the loss of Afghanistan, "a liberated land of jihad," the Islamists desperately needed a new theater from which to wage jihad. Without another "land of jihad," it was impossible to physically and psychologically train a new generation of fighters. The United States' unilateral invasion of Iraq produced the ideal conditions for jihadis. The influx of foreign fighters - both guerrillas and terrorists-bringing with them virulent ideologies and tactics, such as suicide terrorism, has fuelled the Iraqi insurgency. The blueprint for fighting in Iraq was crafted by the Saudi-born Al Qaeda ideologue and operative Yousef Al Aiyyeri. Aiyyeri, a former bodyguard in Sudan, instructor at the Al Farooq training camp in Afghanistan, and later webmaster of Alneda.com, the Al Qaeda website, was killed on 31 May 2003. Urging Muslims to fight the "invading crusader," Al Aiyyeri wrote that if democracy were established in Iraq, it would be the death of Islam. Most Muslims who have come to Iraq to participate in the insurgency-estimated at a few thousand-have come from the Levant, countries neighboring Iraq, the Gulf, and North Africa.

A few hundred cradle and convert Muslims from Europe have also arrived in Iraq to support and train insurgents, fight, and attain martyrdom. In time, in the true spirit of jihad, Asian and North American Muslims will join them. Rich Muslims in Western Europe are helping poor Muslims from Eastern Europe to travel to Iraq. Diaspora Muslims in Germany, France, Italy, and the U.K. are encouraging and funding migrant Muslims - many without proper identity documents - from Bulgaria, the Czech Republic, and Poland to go to Iraq for jihad. This third-country recruitment includes Bosnia-Herzegovina and the rest of the Balkans. Communication is conducted via one-onone meetings and the Internet. Some jihadis travel by road through Turkey and Syria under the guise of providing humanitarian assistance, sell the vehicle at the Iraq border, and enter the new land of jihad.

Unlike the Arabs who went to wage a guerilla war against the Soviets in Afghanistan, these European Muslims are learning terrorist tactics from the moment they arrive in Iraq. When the Arab mujahedeen returned home to the Middle East from Afghanistan, they tried to topple the "false Muslim" rulers and "corrupt Muslim" regimes and replace them with Islamic states. When the European Muslims return home to Europe from Iraq, they will engage in terrorism against the West. Just as Afghanistan, Bosnia, and Chechnya produced the last generation of mujahedeen, Iraq will produce the next generation of terrorists and extremists. The Western response to the lands of jihad will determine the future trends and patterns in Islamist terrorism and extremism.

\section{Prognosis}

The threat of Islamist terrorism will not diminish in the short term. Unless and until Western government leaders and bureaucrats better understand radical Islam, the threat of terrorism and extremism will grow. Addressing the tactical aspects-approaching the issue like a technician-will only lead to an escalation of the threat. Along with targeting the terrorists' operational and support infrastructures, governments must also seek to target their conceptual infrastructures. Along with neutralizing terrorist cells that are planning, preparing, and supporting operations, it is necessary to target ex- 
tremist ideologies and ideologues. At the heart of the fight against terrorism is the effort to counter extremism, the virulent ideologies that generate funds, recruits, andmore importantly_-justify violence. In addition to countering propaganda, the international community should seek to change the reality that gives rise to terrorist movements. The conflicts in Palestine, Kashmir, Chechnya, Mindanao, Afghanistan, and now Iraq provide the ideological rationale and fuel for extremism and terrorism.

The key to fighting the contemporary wave of terrorism is in the development of a holistic approach, in which enduring non-military political, economic, and informational strategies should be given priority. Furthermore, whatever military measures are undertaken should be coordinated with non-military measures. The reason for U.S. failure in Iraq is that only a handful of the U.S. military's generals were able to envision fighting an unconventional opponent in an unconventional manner. As opposed to Iraq, the U.S.-led coalition in Afghanistan developed intelligence dominance, due to the widespread cruelty of the Taliban and the presence of a viable alternative - the Northern Alliance - on the ground. Iraq has demonstrated to the world that, without winning hearts and minds, winning firefights and battles assures no real victory.

Along with fighting the physical enemy, working on the enemy mind and his actual and potential support base is critical. How many U.S. personnel at Abu Ghraib prison in Baghdad understood that every Iraqi tortured and released from detention would turn out to be an enemy who would galvanize countless others to join the cause? Investing billions of dollars in the military realm while neglecting or ignoring the social, cultural, and religious realities offers no chance for victory. Without winning the goodwill of the Iraqi public, Iraq will be a lost cause for the Western coalition. Iraq should offer to the world the critical object lesson that war-fighting alone is inadequate for an army to succeed in its mission.

The unintended consequences of the U.S. invasion of Iraq have created a dangerous situation that the world will have to live with for years to come. Democracy cannot be imposed from outside on a people not ready to embrace it. The best the West could hope for is to economically develop the Middle East and empower the Muslims themselves to fight for greater levels of political representation and participation. With upward social mobility, people in the region will push for leaders worthy of representing their ideas and values. Investments in education and the market economy are more likely to work than the imposition of a Western system of governance. Furthermore, establishing a democracy is likely to create the opportunity for Islamist political parties to capture political power. Just as American pressure on the Shah of Iran to reform facilitated the Iranian revolution, America's project to democratize the Middle East and Central Asia is likely to embolden the Islamist groups that will threaten the very Muslim regimes and rulers that are pro-Western in orientation.

A reassessment of U.S. policy in the Middle East is essential to reduce the level of instability and violence in the region. America's noble intentions of trying to create a free Iraq have created - in the heart of the Middle East instead of on its periphery-a new land of jihad. Just as the Soviet withdrawal from Afghanistan produced the conditions for the creation of a generation of terrorists, Iraq's fallout will destabilize the region - and the world - for a decade at least. In the same way that Afghan alumni trav- 
eled abroad to destroy America's iconic landmarks, Iraqi alumni will seek to harm the United States, its allies, and its friends in the coming months and years. Buoyed by the rising tide of anger, suffering, and resentment in the Muslim world, Islamism will flourish, just as communism did in the last century.

Only through an effort to change the reality of regional conflicts where Muslims are suffering can the threat of terrorism be diminished. In the meanwhile, terrorist ideologues and propagandists will continue to dishonor the name of Allah and his great religion. Most moderate Muslims will be reluctant to challenge the terrorist ideologues and propagandists who misinterpret and misrepresent Islam, because they fear reprisals from the extremists and terrorists. Furthermore, the moderates will be challenged by the extremists - and even by observant Muslims who do not share the extremists' beliefs - as to why they had not spoken up for the Palestinians, Kashmiris, Chechens, and other suffering Muslims. Due to the enshrinement of freedom of speech and similar values in liberal Western democracies, Islamist ideologues will continue to offer a corrupt version of Muslim religious texts, including the Koran, in their effort to politicize, radicalize, and mobilize Muslims against the West. Therefore, the challenge facing the West and the Muslim world from the Islamist terrorists and their ideologues is both formidable and persistent. Given the dynamism of the situation, a greater understanding of the opponent, a deeper knowledge of the issues, and a sustained investment in training and education are essential to win the fight.

\section{Future Research}

For counter-terrorism initiatives to be effective, they must be driven by intelligence. Basic research is intelligence. The state of terrorism research has changed rapidly in the last decade. Traditionally, most terrorism analysts focused on international terrorism, as opposed to domestic or national terrorism. Furthermore, their interest was in European and Middle Eastern groups and left-wing and ethnonationalist ideologies. Very few specialists worked on Asia. New Scotland Yard did not consider South Asian groups - including Pakistani organizations - important. Al Qaeda was neglected by political scientists, who specialize in specific geographic regions. Middle Eastern specialists were narrowly focused on Middle Eastern groups that were active in the Middle East.

Neither political scientists nor scholars of religion paid adequate attention to religiously motivated violence. Until the second half of the 1990s, terrorism analysts conducted their research by reviewing terrorist literature and government reports. Only a handful of researchers ever interviewed serving and detained terrorists, their family members and friends, supporters and sympathizers, or extremist ideologues. Until 9/11, there were only three databases that recorded worldwide incidents of domestic terrorism. As incidents of international terrorism declined throughout the 1990s, governments believed that the threat of terrorism was declining.

Many academics in the field were against the use of the word terrorism prior to 9/11. Only a few understood that it was a concept, like democracy. Government and academic institutions working on terrorism research have grown dramatically recently. 
Although terrorism research centers have proliferated since September 2001, most of these centers are located in the West, and their focus is very much on the threat to the West. Two exceptions are the International Policy Institute for Counter Terrorism Research at the Interdisciplinary Center in Herzliya in Israel, which was created in the Middle East, and the International Center for Political Violence and Terrorism Research at the Institute of Defense and Strategic Studies in Singapore, in the Asia-Pacific.

Along with the research centers, the number of scholars working on political violence has increased several-fold since $9 / 11$. Very few, however, had actually specialized in terrorism research. At the time of the Bali bombings, Australia had only two trained specialists on terrorism, and both worked for the government. Rather than continuing to engage in statistical trend analysis of incidents, more scholars started to engage in functional and regional analysis. Some looked at suicide terrorism and functional issues, and others began to examine North Africa and other regions that have been affected by terrorism. More than ever before, counter-terrorism research centers are developing the basic building blocks of terrorism research: terrorist group, personality, and attack profiles. Due to data protection laws, North American, European, and Australasian institutions had difficulty in collecting and analyzing data relating to individual terrorists until they were convicted. Similarly, the West faced difficulties in developing profiles of extremist groups and their leaders - that is, groups that preached violence but did not directly engage in violence.

Before September 11, most academics that worked on political violence engaged in "ivory-tower research" - research for the sake of research, and with limited policy application. But now governments are cooperating with private research institutions. For instance, Steve Emerson's Investigative Project and Rita Katz's SITE Institute conducted research for the U.S. and Swiss governments, respectively. Hard pressed for time, government analysts mostly work at the tactical end. It is imperative for terrorism analysts from the academic and policy communities to work together, because government analysts lack the resources to work at the strategic end. Neither the think tanks of the elite forces, including the U.S. Delta Force or the British SAS, or Western intelligence services systematically analyzed the terrorist training manuals recovered from Afghanistan and elsewhere for terrorist technologies, tactics, and techniques. The training manuals offered a condensed view of what the terrorist knows, and what he is capable of; they also offered a glimpse of what the terrorists are incapable of and their limitations.

By educating special forces, commandos, airborne troops, and other elite forces regarding terrorist devices and their modes of operation, it is possible to better prepare government troops designated for front-line operations before they are forced to learn under battle conditions. At all levels, solid training and education-both formal and informal-is essential to ensure sound decision- and policy-making, whether it is by a head of state or a soldier conducting a raid. As much as decisive leadership, research and education are essential for military forces, law enforcement authorities, and intelligence services to make better, more informed judgments at the levels of policy, strategy, operations, and tactics. 


\section{Bibliography}

Allen, Nick. "Lack of Training: Terrorist Attacks: We Need More Training - Police." The Scotsman (2004).

Atran, Scott. "Genesis of Suicide Terrorism." Science 229 (2003).

Atran, Scott. "Individual Factors in Suicide Terrorism." Science 304 (2004): 47-49.

Bell, Stewart. Cold Terror: How Canada Nurtures and Exports Terrorism Around the World. Toronto: John Wiley \& Sons, 2004.

Davidson, Lawrence. Islamic Fundamentalism. Westport, CT: Greenwood Press, 1998.

Dolnik, Adam, and Richard Pilch. "The Moscow Theater Incident: Perpetrators, Tactics, and the Russian Response." International Negotiation 8, no. 3 (2003).

Gruen, Madeleine. "White Ethnonationalist and Political Islamist Methods of Fundraising and Propaganda on the Internet." In The Changing Face of Terrorism, ed. Rohan Gunaratna, 127. Singapore: Eastern Universities Press, 2004.

Gunaratna, Rohan. "The Terrorist Threat to the Continent." In Meeting of the Special Committee of NATO, Ministry of Foreign Affairs. Copenhagen, 2004.

Gunaratna, Rohan. Inside Al Qaeda: Global Network of Terror. New York: Columbia University Press, 2002.

Hoffman, Bruce. Inside Terrorism . London: Victor Gollancz, 1998.

Isikoff, Michael. "9-11 Hijackers: A Saudi Money Trail: The Feds Probe a Possible New Saudi Link to Al Qaeda." Newsweek (2002).

King, Gilbert. Dirty Bomb: Weapons of Mass Disruption. New York: Chamberlain Bros, 2004.

Paz, Reuven. Tangled Web: International Networking of the Islamist Struggle. Washington, D.C.: Washington Institute for Near East, 2002.

Smucker, Philip. Al Qaeda's Greatest Escape: The Military and the Media on Terror's Trial. Washington, D.C.: Brassey's, 2004.

Wilkinson, Paul. Terrorism Versus Democracy: The Liberal State's Response. London: Frank Cass, 2001.

Zawahiri, Ayman Al. "Knights Under the Prophet's Banner-Meditations on the Jihadist Movement." Al-Sharq al-Awsat (2001). 